\title{
Effect of Fe Nanoparticles of Seeds with Commercial Importance in Guanajuato, Mexico
}

\author{
Edgar Vázquez-Núñez, Jessica Denisse Valle-García \\ Department of Chemical, Electronics and Biomedical Engineering, University of Guanajuato \\ Lomas del Bosque 103 León, Guanajuato, México, MX37150 \\ edgar.vazquez@ugto.mx; vallegj2013@licifug.ugto.mx
}

\begin{abstract}
The effect of $\mathrm{Fe}\left(\mathrm{FeO}_{2}\right)$ nanoparticles on the percentage of germination and root elongation of carrot (Daucus carota), tomato (Solanum lycopersicum), broccoli (Brasica oloracea) and alfalfa (Medicago sativa) was investigated. The seeds were imbibed in solution of nanoparticles at different concentrations i.e., 500 and $1000 \mathrm{mg} \mathrm{L}^{-1}$ and incubated during 14 days. The number of germinated seed was registered at days 3, 7 and 14; the Kotowsky's coefficient was calculated and the length of the roots was measured at the end of the experiment. The highest Kotowsky's coefficient value was obtained for all the seeds imbibed in $50 \mathrm{mg} \mathrm{L}^{-1}$. It was observed inhibition of roots growth in seeds treated at $1000 \mathrm{mg} \mathrm{L}^{-1}$. It was confirmed an inhibition dependent of the concentration of nanoparticles.
\end{abstract}

Keywords: Kotowski’s coefficient, germination, rootlet growth, toxicity

\section{Introduction}

The use of nanotechnology in industries such as medicine, energy, cosmetics, and agriculture has increased rapidly, and as such, concerns over the risk of nanomaterial exposure to the environment and to human health have been frequently raised [1]. It is now widely recognized that there is insufficient understanding of the fate and effects of nanoparticles in soil and plant systems. Although nanoparticle (NP) toxicity is still an area of active investigation, several studies have demonstrated negative effects on biota from NP exposure, including genotoxicity and cytotoxicity to plants (Cucurbita pepo L., Solanum lycopersicum L., and Zea mays L.) [2] In our research group was interesting to analyze the effect of Fe nanoparticles $\left(\mathrm{FeO}_{2}\right)$ on the germination rate and growth of four vegetable seeds: carrot (Daucus carota), tomato (Solanum lycopersicum), broccoli (Brasica oloracea) and alfalfa (Medicago sativa); all of them have an important economic value in the Mexican state of Guanajuato [3].

\section{Material and Methods}

\subsection{Conditioning of Seeds}

Commercial dehydrated seeds were soaked in distilled water during $30 \mathrm{~min}$; after that the seeds were dried and selected.

\subsection{Description of Treatments}

Four treatments were established, a) treatment control (TC): distilled water without nanoparticles; b) treatment T50: Fe nanoparticles at $50 \mathrm{mg} \mathrm{L}-1$; c) treatment T500: Fe NP at $500 \mathrm{mg} \mathrm{L}-1$ and d) treatment T1000: Fe nanoparticles at 1000 mg L-1.

\subsection{Incubation}

The dishes of Wathman ${ }^{\circledR}$ filter N 50 were imbibed in treatment solution i.e., TC, T50, T500 and T1000 respectively; and placed in Petri dishes; twenty seeds were placed in the Petri dish per triplicate per treatment and kind of vegetable.

The dishes were sealed and incubated at $30 \pm 3{ }^{\circ} \mathrm{C}$ during 14 days. 


\subsection{Sampling}

The samples were taken at 1, 37 and 14 days.

The number of germinated seeds was determined during the 14 days and the Kotowski's velocity coefficient was calculated; the root and rootlets length was measured and the growth rate was estimated.

The statistical analysis was done by using the Tukey's HSD test using the statistics software SPSS 16 (Statistical Package for the social Sciences, Chicago,IL).

\section{Results}

\subsection{Kotowski's Coefficient}

The velocity coefficient was estimated during 14 days of incubation.

Table 1: Kotowski's index values for analyzed seeds.

\begin{tabular}{|l|l|l|l|l|}
\hline & \multicolumn{4}{|l|}{ Fe nanoparticles $\left(\mathrm{mg} \mathrm{L}^{-1}\right)$} \\
\hline & Control & 50 & 500 & 1000 \\
\hline D. carota & 9 & 20 & 9 & 6 \\
\hline S. lycopersicum & 12 & 19 & 9 & 11 \\
\hline B. oloracea & 12 & 21 & 12 & 10 \\
\hline M. sativa & 10 & 25 & 115 & 11 \\
\hline
\end{tabular}

\subsection{Germination Percentage and Rootlets Length}

After 14 days the percentage of germination for all the seeds was highest for those incubated in Fe-NP at $50 \mathrm{mg} \mathrm{L}^{-1}$ (carrot, 94\%; tomato, 80\%; broccoli, 83\% and alfalfa, 100\%), the same behavior was observed for the length of the rootlets for all the vegetables. It was observed statistical difference $(\mathrm{p}<0.05)$ between the length of seeds at 0,500 and $1000 \mathrm{mg} \mathrm{L}^{-1}$. The smallest growth of the rootlets was registered in seeds incubated at $1000 \mathrm{mg} \mathrm{L}^{-1}$.

\section{Discussion}

Germination is normally known as a physiological process beginning with water imbibition by seeds and culminating in the emergence of the rootlet [4]. However, there are different definitions of seed germination according to its root length: emergence of root,

$>1 \mathrm{~mm}$ or $>5 \mathrm{~mm}$ [5]. In this study, seeds showing emergence of radicle were recorded as being germinated.

Seed coat plays a very important role in protecting the embryo from harmful external factors. Seed coats can have selective permeability [6].

Pollutants, though having obviously inhibitory effect on root growth, may not affect germination if they cannot pass through seed coats. This may explain that seed germination in this study was altered by nanoparticles. The dose-dependent response of seeds was observed in our experiment. The seeds soaked in $50 \mathrm{mg} \mathrm{L}^{-1}$ showed the maximum values for Kotowski's coefficient and length of rootlets, however at higher concentration i.e., 500 and $1000 \mathrm{mg} \mathrm{L}^{-1}$ the growth of roots and velocity of growth were reduced.

Since roots are the first target tissue to confront with excess concentrations of pollutants, toxic symptoms seem to appear more in roots rather than in shoots [7]. Further analysis will be done in order to describe the impact of Fe-NP on the growth of shoots in soil and greenhouse conditions.

\section{Conclusion}

In conclusion we report in this study the effect of Fe nanoparticles on the germination and growth of four important seeds in the Mexican state of Guanajuato. It was important to review what could be the effects on the agricultural productivity in soils in case of been polluted with nanoparticles. It was important to observe that the growth rate was positively affected by nanoparticles at low concentration of $\mathrm{FeO}_{2} \mathrm{NP}$, however a negative effect was detected when the seeds were incubated at $1000 \mathrm{mg} \mathrm{FeO}_{2} \mathrm{~L}^{-1}$. 
Currently, some analyses are being developed trying to explain the localization of the nanoparticles and its effect on the protein expression.

\section{Acknowledgements}

E. Vázquez-Núñez would like to thank to Jessica D. Valle-García for her technical assistance and to DIQEB-DCI-UG and SEP-PRODEP (Project UGTO-PTC-571) for the financial support.

\section{References}

[1] K. Hund-Rinke, M. Simon, "Ecotoxic effect of photocatalytic active nanoparticles (TiO2) on algae and daphnids," Environ Sci Pollut R., vol. 13, no. 4, pp. 225-232, 2006.

[2] D. Stampoulis, S. K. Sinha, J. C. White, “Assay-dependent phytotoxicity of nanoparticles to plants," Environ Sci Technol., vol. 43, no. 24, pp. 9473-9479, 2009.

[3] N. Scott, H. Chen, "Nanoscale science and engineering for agriculture and food systems," Ind Biotech, vol. 9, no. 1, pp. 17-18, 2013.

[4] A. V. A. Garay, R. S. Rindermann, B. C. Chávez, "Hortalizas en México: competitividad frente a EE. UU. y oportunidades de desarrollo/Vegetables in Mexico: from US competitiveness and opportunities for development/Legumes no México: competitividade face à UE e oportunidades de desenvolvimento," Revista de Globalización, Competitividad y Gobernabilidad, vol. 6, no. 3, p. 70, 2012.

[5] W. E. Finch-Savage, G. Leubner-Metzger, "Seed dormancy and the control of germination," New Phytol, vol. 171, no 3, pp. 501-523, 2006.

[6] C. W. Lee, S. Mahendra, K. Zodrow, D. Li, Y.C. Tsai, J. Braam, P. J. Alvarez, "Developmental phytotoxicity of metal oxide nanoparticles to Arabidopsis thaliana," Environ Toxicol Chem, vol. 29, no. 3, pp. 669-675, 2010.

[7] T. Adhikari, S. Kundu, A. K. Biswas, J. C. Tarafdar, A. S. Rao, "Effect of copper oxide nano particle on seed germination of selected crops," J Agr Sci Tech,. vol. 2, no. 1, p. 815, 2012. 